\title{
Prolonged exposure of pancreatic beta cells to raised glucose concentrations results in increased cellular content of islet amyloid polypeptide precursors
}

\author{
X. Hou, Z. Ling, E. Quartier, A. Foriers, F. Schuit, D. Pipeleers, C. Van Schravendijk \\ Diabetes Research Center, Vrije Universiteit Brussel, Brussels, Belgium
}

\begin{abstract}
Summary Most non-insulin dependent diabetic patients have amyloid deposits in their pancreatic islets. It is not known whether chronic hyperglycaemia contributes to the formation of amyloid fibrils from the islet amyloid polypeptide that is produced by the pancreatic beta cells. Since islet amyloid exhibits islet amyloid polypeptide precursors immunoreactivity, we examined whether sustained in vitro exposure to raised glucose increases the abundance of these precursors in human beta cells. After 6 days stimulation with $20 \mathrm{mmol} / \mathrm{l}$ glucose the cellular content of insulin but not islet amyloid polypeptide was decreased leading to an increase in the ratio of the latter over insulin $(3.0 \pm 0.6$ vs $1.8 \pm 0.3$ after $6 \mathrm{mmol} / 1$ glucose culture, $p<0.05)$. Similar changes occurred in rat beta cells cultured for 3 days in the presence of $20 \mathrm{mmol} / 1 \mathrm{glu}$ cose plus 3-isobutyl-1-methylxanthine. Western blot
\end{abstract}

analysis of cellular islet amyloid polypeptide after prolonged exposure to high glucose indicated the presence of higher proportions of its precursor- and intermediate forms. In human beta cells cultured in $20 \mathrm{mmol} / \mathrm{l}$ glucose, the major form corresponds to an intermediate species which exhibits an immunoreactivity for the N-flanking peptide, as is also the case in islet amyloid. We concluded that prolonged in vitro exposure of beta cells to raised glucose concentrations increases the relative proportion of islet amyloid polypeptide over insulin, as well as of its precursors over the mature form of islet amyloid polypeptide. [Diabetologia (1999) 42: 188-194]

Keywords Islet amyloid, pancreatic beta cells, Type II (non-insulin-dependent) diabetes mellitus, peptide precursors, amylin.
Islet amyloid polypeptide (IAPP) is a 37 amino acid peptide that is produced by pancreatic beta cells following synthesis of (pre)pro-IAPP and proteolytic cleavage at dibasic lys-arg residues [1]. The peptide is the predominant component of the amyloid deposits which are often observed in pancreatic islets of non-insulin dependent diabetic patients [2,3]. Formation of amyloid fibrils appears dependent on an

Received: 1 April 1998 and in final revised form: 13 October 1998

Corresponding author: Dr. C.F.H. Van Schravendijk, Department of Metabolism and Endocrinology, Vrije Universiteit Brussel, Laarbeeklaan 103, B-1090 Brussels, Belgium Abbreviations: IAPP, Islet amyloid polypeptide; IBMX, 3isobutyl-l-methylxanthine; BSA, bovine serum albumin; PBS, phosphate buffered saline. amyloidogenic region (amino acids 20-29) in the IAPP-amino acid sequence, known to be present in the human peptide $[4,5]$. Overproduction and increased secretion of IAPP have been suggested to be predisposing conditions $[6,7]$ but their relation to amyloid formation is not yet understood [8]. Newly diagnosed patients with Type II (non-insulin-dependent) diabetes have increased circulating concentrations of IAPP-like immunoreactivity, containing high MW IAPP-like peptides [9]. Islet amyloid polypeptide precursors also seem to be present in the amyloid deposits, as documented by their immunocytochemical reactivity for a flanking peptide sequence of pro-IAPP [10]. It is still not clear to which extent precursor forms are present in islet beta cells and whether continuously raised glucose concentrations - as occurring in non-insulin dependent diabetes can increase their abundance, intra- and extracellu- 
larly. Our study investigates this question in cultured rat and human beta cell preparations.

\section{Materials and methods}

Rat beta cells. Pancreatic islets were isolated from male adult Wistar rats using a modified collagenase digestion method and dissociated in a calcium-free medium containing trypsin and DNase [11]. Single beta cells were purified from the islet cell suspensions by autofluorescence [11]. Purified beta cells were reaggregated for $2 \mathrm{~h}$ in a rotatory shaking incubator $\left(37^{\circ} \mathrm{C}\right.$, Braun, Melsungen, Germany) [12], suspended in Suspension Culture Dish (Nunc, Inc., Roskilde, Denmark) $35 \times 10$ (200-300 K cells per dish), containing 3 ml Ham's F10 (GIB$\mathrm{CO}$, Strathclyde, UK) at 6 or $20 \mathrm{mmol} / \mathrm{l}$ glucose with or without 3-isobutyl-1-methylxanthine (IBMX; $50 \mu \mathrm{mol} / 1$ Janssen Chimica, Beerse, Belgium), supplemented with $2 \mathrm{mmol} / 1 \mathrm{CaCl}_{2}$, $2 \mathrm{mmol} / \mathrm{l}$ glutamine, $0.075 \mathrm{mg} / \mathrm{ml}$ penicillin and $0.1 \mathrm{mg} / \mathrm{ml}$ streptomycin, $1 \%(\mathrm{wt} / \mathrm{vol})$ bovine serum albumin (BSA) (Fraction V, Sigma, St. Louis, Mo., USA) and cultured for 3 days. Culture media were changed after 2 days. Medium and cells were collected for determination of insulin and IAPP by radioimmunoassay. Cells were washed three times with phosphate buffered saline (PBS) and extracted for SDS-PAGE and western blot. Media were diluted twofold in sample buffer and then further processed for SDS-PAGE and western blot.

Human islet cells. Human pancreata were processed within the framework of Beta-Cell Transplant, a collaborative programme on islet cell transplantation in diabetes [13]. This study was conducted on samples of tissue and islets that were made available by this programme. Islet fractions were isolated from the digest by ficoll gradient centrifugation and then precultured 1 or 2 days in Ham's F10 medium containing $0.5 \%$ BSA (Fraction V, Boehringer, Mannheim, Germany), $2 \mathrm{mmol} / \mathrm{l}$ glutamine, $6.1 \mathrm{mmol} / \mathrm{l}$ glucose, $0.075 \mathrm{mg} / \mathrm{ml}$ penicillin and $0.1 \mathrm{mg} / \mathrm{ml} \mathrm{strep}-$ tomycin, $2 \mathrm{mmol} / \mathrm{l}$ leucine, $2 \mathrm{mmol} / \mathrm{l}$ nicotinamide and $2 \%$ human serum [14]. After preculture, preparations consisted of $50-70 \%$ endocrine cells, with $50 \%$ or more insulin-positive cells [14]. Cells were further cultured for 6 days in serum-free Ham's F10 medium supplemented with $1 \% \mathrm{BSA}, 2 \mathrm{mmol} / \mathrm{l}$ $\mathrm{CaCl}_{2}, 6$ or $20 \mathrm{mmol} / \mathrm{l}$ glucose, with or without IBMX $(50 \mu \mathrm{mol} / 1)$; media were changed after 3 days. All media were collected for radioimmunoassay of insulin and IAPP and cells were taken for hormone assays or for SDS-PAGE and western blot. In some experiments, cells were also taken immediately after isolation, or after a culture period of 3 days.

Islet amyloid polypeptide antibodies. The IAPP antiserum for western blot was raised in rabbits by subcutaneous injection of KLH-bound rat IAPP and Freund's Adjuvants (Gibco). Cross reactivity was $0.01 \%$ with human calcitonin-gene related peptide and undetectable with human and rat insulin, human proinsulin, somatostatin, human pancreatic polypeptide or glucagon. Antiserum was purified by affinity adsorption to a column containing $3 \mathrm{mg}$ IAPP covalently coupled (Peninsula, Belmond, Calif., USA) to $3 \mathrm{ml}$ Affi-Gel 10 (Bio-Rad, Hercules, Calif., USA). After loading, the column was washed with $10 \mathrm{mmol} / \mathrm{l}$ Tris (pH 7.5) and with $500 \mathrm{mmol} / \mathrm{l} \mathrm{NaCI}-10 \mathrm{mmol} / \mathrm{l}$ Tris (pH 7.5) and then eluted with $100 \mathrm{mmol} / \mathrm{l}$ glycine $\mathrm{pH} 2.5$ and immediately neutralised by collection in tubes containing $50 \mu \mathrm{l}$ of $1 \mathrm{~mol} / 1$ Tris (pH 8.0). The eluted protein was analysed by UV monitor (2158 UVICORD SD LKB, Bromma, Sweden) and peak fractions pooled. After concentration by Centricon30 (Amicon), antibody samples were diluted with an equal vol- ume of $20 \mathrm{mmol} / \mathrm{l}$ phosphate buffer (pH 7.6), $150 \mathrm{mmol} / \mathrm{l} \mathrm{NaCl}$ $0.5 \% \mathrm{BSA}$ and stored at $-20^{\circ} \mathrm{C}$. Affinity-purified antiserum was further treated by absorption to liver acetone powder $(4 \mathrm{~h}$ at $37^{\circ} \mathrm{C}$ ), before its use in western blots. $\mathrm{N}$ - and $\mathrm{C}$-terminal flanking peptide-directed polyclonal antibodies (made by $\mathrm{C}$. Edwards, Nottingham, and kindly provided by A. Clark, Oxford, UK) to the $\mathrm{N}$ - and C-terminal flanking peptides of human pro-IAPP were also used in western blot analysis of human samples, to further identify the higher MW bands of IAPP. These antibodies are raised to the complete sequence of the flanking peptides and are human-specific. Rabbit anti-human amylin serum RIN 7321 (Peninsula) was used for radioimmunoassay of IAPP; this antibody is fully cross-reactive with rat IAPP. In the absence of pure precursor peptides, its cross-reactivity with pro-IAPP and its conversion intermediates could not be determined; in western blot, control experiments indicated that this antibody (used in excess) also recognises the higher MW species of IAPP (data not shown).

Peptide separation and analysis. For analysis of proteins with molecular mass under $20 \mathrm{kDa}$, samples were separated on Tris/tricine $20 \%$ SDS-PAGE [15]. Cell pellets were washed in PBS, resuspended in $4 \%$ SDS, $12 \%$ glycerol (w/v) $50 \mathrm{mmol} / 1$ Tris, $2 \%$ mercaptoethanol (v/v), $0.01 \mathrm{~g} / 100 \mathrm{ml}$ bromophenolblue (sample buffer), then sonicated (Branson, Sonifier 250, Danbury, Conn., USA) and heated for $5 \mathrm{~min}$ at $100^{\circ} \mathrm{C}$. Gel loading was standardised on the basis of $80 \mathrm{k}$ beta-cell equivalents (rat beta cells) or approximately $20 \mathrm{ng}$ IAPP content, determined in RIA (human islet cells). Electrophoresis was done at $100 \mathrm{~V}$ and proteins were transferred at low voltage to nitrocellulose membranes (25 V; Schleicher and Schuell, Dassel, Germany). The blots were blocked with $5 \%$ non-fat dry milk (Regilait, St.-Martin-Belle-Roche, France) and then incubated with purified anti-IAPP. After washing, the blots were incubated with sheep anti-rabbit Ig-HRP (Amersham, Buckinghamshire, UK). Immunoreactivity was detected using Enhanced Chemiluminescence on X-OMATLS film (ECL detection reagents, Amersham). Films were scanned in optical reflectance for quantification (Ultroscan XL, LKB, Bromma, Sweden). Membranes blotted with pure synthetic rat IAPP (Peninsula, Merseyside, UK) after SDS-PAGE, showed a linear dose relation for concentrations ranging from 0.75 to $50 \mathrm{ng}$ per lane. Efficient trapping of IAPP by the blotting membrane was confirmed by the absence of IAPP immunoreactivity on a second membrane present underneath the first during electrotransfer. In each experiment, the relative density of each IAPP-immunoreactive band was determined and expressed as per cent of the total density of all IAPP-immunoreactive bands; data of independent experiments were statistically analysed.

The position of the intact IAPP precursor in SDS-PAGE was determined in pulse labelled rat beta cells. In brief, purified rat beta cells were preincubated in RPMI 1640 (Paisley, Scotland) without cysteine for $30 \mathrm{~min}$ and then exposed to ${ }^{35}$ S-cysteine (37 MBq/100 $\mu$, ICN, Irvine, Calif., USA) for $30 \mathrm{~min}$ followed by a rapid wash in cold RPMI containing $1 \mathrm{~mol} / \mathrm{l}$ cysteine. Cell pellet was dissolved in lysis buffer, briefly centrifuged and supernatant immunoprecipitated with affinitypurified IAPP antibody. Immune complex was absorbed to protein-A Sepharose, washed, taken up in sample buffer, boiled for $5 \mathrm{~min}$, run over SDS-PAGE and visualised by fluorography.

Glycosylation of IAPP-immunoreactive bands was investigated using an enzymatic deglycosylation kit (Bio-Rad). Rat beta cells were cultured at $20 \mathrm{mmol} / \mathrm{l}$ glucose for 2 days, washed in PBS, frozen, thawed and sonicated, then taken up in reaction buffer and exposed to NANase-II and O-Glycosidase for $1 \mathrm{~h}$ at $37^{\circ} \mathrm{C}$. After addition of $\mathrm{pH}$ adjustment buffer and de- 
Table 1. IAPP and insulin contents in rat beta cells and culture media

\begin{tabular}{|c|c|c|c|c|c|c|c|}
\hline \multirow{2}{*}{$\begin{array}{l}\text { Culture } \\
\text { Condition: }\end{array}$} & \multicolumn{3}{|l|}{ Cell } & \multicolumn{2}{|l|}{ Medium } & \multicolumn{2}{|l|}{ Total } \\
\hline & $\begin{array}{l}\text { IAPP } \\
\left(\mathrm{fmol} \cdot 10^{-3}\right. \\
\text { beta cell })\end{array}$ & $\begin{array}{l}\text { insulin } \\
\left(\mathrm{pmol} \cdot 10^{-3}\right. \\
\text { beta cell) }\end{array}$ & $\begin{array}{l}\text { Ratio } \\
\text { IAPP/ } \\
\text { insulin (\%) }\end{array}$ & $\begin{array}{l}\text { IAPP } \\
\left(\mathrm{fmol} \cdot 10^{-3} \text { beta }\right. \\
\left.\text { cell } \cdot 3 \text { days }^{-1}\right)\end{array}$ & $\begin{array}{l}\text { insulin } \\
\left(\mathrm{pmol} \cdot 10^{-3} \text { beta }\right. \\
\left.\text { cell } \cdot 3 \text { days }^{-1}\right)\end{array}$ & $\begin{array}{l}\text { IAPP } \\
\left(\mathrm{fmol} \cdot 10^{-3}\right. \\
\text { beta cell })\end{array}$ & $\begin{array}{l}\text { insulin } \\
\left(\mathrm{pmol} \cdot 10^{-3}\right. \\
\text { beta cell })\end{array}$ \\
\hline \multicolumn{8}{|l|}{ Glucose $6 \mathrm{mmol} / \mathrm{l}$} \\
\hline Control & $11.7 \pm 0.9$ & $1.5 \pm 0.2$ & $0.8 \pm 0.1$ & $6.2 \pm 0.8$ & $1.2 \pm 0.1$ & $17.9 \pm 0.6$ & $2.7 \pm 0.1$ \\
\hline IBMX & $10.9 \pm 1.1$ & $1.3 \pm 0.1$ & $0.9 \pm 0.1$ & $26.2 \pm 3.2^{\mathrm{a}}$ & $8.5 \pm 1.3^{\mathrm{a}}$ & $37.0 \pm 4.2^{\mathrm{a}}$ & $9.8 \pm 1.3^{\mathrm{a}}$ \\
\hline \multicolumn{8}{|l|}{ Glucose $20 \mathrm{mmol} / \mathrm{l}$} \\
\hline Control & $18.2 \pm 0.8^{\mathrm{b}}$ & $1.4 \pm 0.2$ & $1.4 \pm 0.2$ & $90.0 \pm 14.3^{\mathrm{b}}$ & $16.5 \pm 2.3^{b}$ & $108.1 \pm 14.8^{\mathrm{b}}$ & $17.8 \pm 2.2^{\mathrm{b}}$ \\
\hline IBMX & $11.4 \pm 0.4^{\mathrm{a}}$ & $0.4 \pm 0.1^{\mathrm{abc}}$ & $2.9 \pm 0.5^{\mathrm{abc}}$ & $184.1 \pm 29.9^{\mathrm{abc}}$ & $22.5 \pm 2.1^{b c}$ & $195.7 \pm 30.1^{\mathrm{abc}}$ & $22.9 \pm 2.0^{\mathrm{bc}}$ \\
\hline
\end{tabular}

Rat beta cells were cultured in HAM F10 (supplemented with $2 \mathrm{mmol} / \mathrm{l} \mathrm{CaCl}_{2}$ ) at the indicated conditions. After 3 days, insulin and IAPP were measured in cellular extracts and culture medium by radio immuno assay. Data represent means \pm SEM, $n=4 ;{ }^{\mathrm{a}} p<0.05$ vs control at corresponding glucose, ${ }^{\mathrm{b}} p<0.05$ vs corresponding condition at $6 \mathrm{mmol} / 1$ glucose, ${ }^{\mathrm{c}} p<0.001$ vs $6 \mathrm{mmol} / \mathrm{l}$ glucose control naturing solution followed by boiling for $5 \mathrm{~min}, \mathrm{NP}-40$ and PNGase-F were added to the reaction vial and incubation continued for $3 \mathrm{~h}$ at $37^{\circ} \mathrm{C}$. A control sample was run in parallel without addition of the enzymes. Bovine fetuin was used as a positive control, run over $7.5 \%$ SDS-PAGE and stained with Coomassie Blue.

For radioimmunoassay, rat IAPP was labelled with ${ }^{125} \mathrm{I}$ (IMS-30, Amersham, Bucks, UK) using a modified chloramine-T method [16]. Mono-iodinated rat ${ }^{125}$ I-IAPP was prepared by reversed phase HPLC on a $\mu$ Bondapack C18 column $(300 \times 3.9 \mathrm{~mm}$ inner diameter, particle size $10 \mu \mathrm{m})$. The IAPP radioimmunoassay was done in a two-step incubation; IAPP standards (human or rat) or samples were first incubated with antiserum (RIN 7321 - Peninsula) for $24 \mathrm{~h}$ and ${ }^{125}$ I-IAPP was added for $6 \mathrm{~h}$ at $4{ }^{\circ} \mathrm{C}$. Bound and free IAPP were separated by Pharmacia Decanting suspension no. 3 (Uppsala, Sweden). Each sample was tested in at least two dilutions and data accepted when parallel to the standard curve; this was the case in the majority of measurements. Medium without IAPP did not differ from the assay blank. The inter-assay and intra-assay coefficients of variation were 8 and $7 \%$, respectively. The insulin radioimmunoassay was carried out as described previously [12]; its cross reactivity with proinsulin was $25 \%$ [17].

Statistical analysis. In rat beta cells, data were expressed as a function of the beta-cell number at start of culture. In human islet preparations, cellular and medium IAPP and insulin content were expressed per equivalent starting fraction. Results are expressed as means \pm SEM. Statistical significance of differences was calculated by analysis of variance (ANOVA).

\section{Results}

Stimulation of IAPP and insulin release from cultured rat beta cells. The release of IAPP and insulin from cultured rat beta cells is stimulated 4- to 15 -fold by the presence of IBMX or of raised glucose concentrations in the medium (Table 1). After 3 days of stimulated release the cellular IAPP and insulin contents were not lower than in the $6 \mathrm{mmol} / \mathrm{l}$ glucose control, suggesting an associated rise in hormone synthesis. This assumption is indirectly supported by the higher total amounts of IAPP and insulin that are recovered from the media plus cells (Table 1). When the effect of culture in $20 \mathrm{mmol} / \mathrm{l}$ glucose is assessed in the presence of IBMX the release of both peptides is also increased but to a greater extent for IAPP (7-fold) than for insulin (2.5-fold). On the other hand, this condition resulted in a 3 -fold lower cellular insulin content whereas that of IAPP was comparable with the control values. The data of total hormone recovery suggest that this condition is also associated with an increased hormone formation but that the increase is smaller for insulin than for IAPP. This relative failure to sufficiently increase insulin formation seems responsible for the 3 -fold increased ratio in cellular IAPP over insulin (Table 1).

Identification of IAPP-like peptides in islet cells. We detected three major IAPP-immunoreactive bands in western blots after SDS-PAGE of human or rat islet cells. A $4 \mathrm{kDa}$ band comigrates with pure synthetic rat IAPP (not shown). A $7.5 \mathrm{kDa}$ band was located in the position of the only radioactive band that appeared after immunoprecipitation of rat islet beta cells following a $30 \mathrm{~min}$ pulse with ${ }^{35} \mathrm{~S}$-cysteine (Fig. 1). In human islet cell extracts, this $7.5 \mathrm{kDa}$ band was immunostained by both $\mathrm{N}$ - and C-terminal flanking peptide-directed antibodies (Fig. 1). An intermediate band runs above the $6.2 \mathrm{kDa}$ standard but is located at $5.7 \mathrm{kDa}$ when its position is interpolated from those of the $4 \mathrm{kDa}$ and $7.5 \mathrm{kDa}$ IAPP-forms; this band shows an immunoreactivity with the N-terminal (Fig. 1), but not with the C-terminal flanking peptidedirected antibody (Fig. 1) and is therefore considered as an $\mathrm{N}$-terminally extended intermediate precursor form. The positions of the three major IAPP-bands do not change after deglycosylation, although the faint bands above the intact pro-IAPP and N-terminal proIAPP disappeared (Fig.1). Bovine fetuin, a glycosylated protein used as a positive control, did shift to a lower MW position after deglycosylation (not shown).

Characterisation of IAPP-like peptides in cultured rat beta cells. After culture at $6 \mathrm{mmol} / \mathrm{l}$ glucose, rat beta 


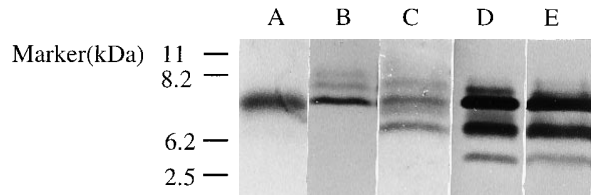

Fig. 1. Characterisation of IAPP-like immunoreactivity after $20 \%$ SDS-PAGE. A Fluorography of rat beta cells pulse-labelled with ${ }^{35} \mathrm{~S}$-cysteine, followed by extraction and immunoprecipitation with IAPP antibody. B Western blot of human islet cell extract using antibody specific for the C-terminal flanking peptide of human IAPP. C Western blot of human islet cell extract using antibody specific for the N-terminal flanking peptide of human IAPP. D Western blot of rat beta cell - extract before and $-\mathbf{E}$ after enzymatic deglycosylation

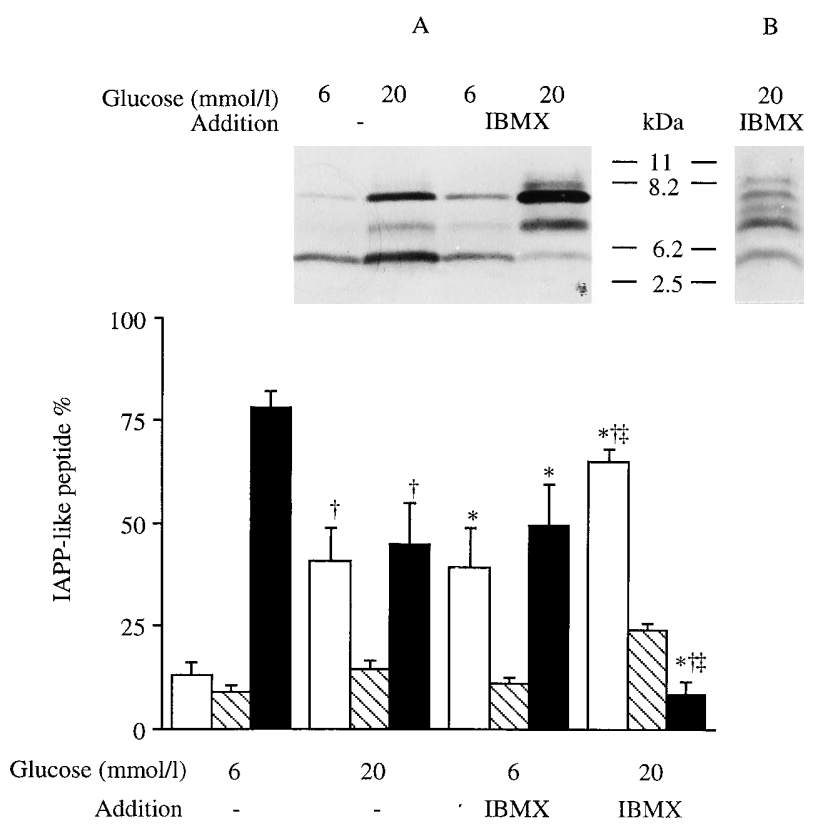

Fig. 2. A Western blot analysis of IAPP-like immunoreactivity in rat beta cells after culture under the indicated conditions for 3 days. The upper panel shows a representative blot. Scanning data were obtained from 4 independent experiments and expressed as per cent of total IAPP-like immunoreactivity (lower panel). The $7.5 \mathrm{kDa}$ species is represented by open bars, the intermediate species by hatched bars and the mature $4 \mathrm{kDa}$ species by black bars. Data are presented as means \pm SEM $* p<0.05$ vs control at corresponding glucose, $\dagger p<0.05$ vs corresponding condition at $6 \mathrm{mmol} / \mathrm{l}$ glucose. $\$ p<0.001 \mathrm{vs}$ $6 \mathrm{mmol} / \mathrm{l}$ glucose control. B Western blot analysis of IAPPlike immunoreactivity in the medium of rat beta cells after culture at $20 \mathrm{mmol} / \mathrm{l}$ glucose in the presence of IBMX

cells show three IAPP-immunoreactive bands with a predominance of the $4 \mathrm{kDa}$ band (Fig. 2). The three conditions which stimulated IAPP release and total IAPP, decreased the abundance of the mature $4 \mathrm{kDa}$ form and increased that of the $7.5 \mathrm{kDa}$ precursor. The most profound alteration was measured after culture at $20 \mathrm{mmol} / \mathrm{l}$ glucose with IBMX, leading to a predominant $7.5 \mathrm{kDa}$ band and a minor $4 \mathrm{kDa}$ band (Fig. 2). The IAPP precursor forms are also re- leased into the medium, as shown by analysis of the medium after culture at $20 \mathrm{mmol} / \mathrm{l}$ glucose plus IBMX (Fig. 2): only $17 \pm 3 \%$ (means \pm SEM, $n=4$ ) of IAPP immunoreactivity was now recovered in the $4 \mathrm{kDa}$ form. This analysis could not be made after culture at $6 \mathrm{mmol} / \mathrm{l}$ glucose since that condition did not reach the detection level of the western blot.

Stimulation of IAPP and insulin release from cultured human beta cells. The release of IAPP and insulin from cultured human beta cells is stimulated two to threefold by the presence of IBMX or of raised glucose concentrations in the medium. After 6 days of $20 \mathrm{mmol} / \mathrm{l}$ glucose stimulation, the cellular insulin content is two to threefold decreased but not that of IAPP (Table 2); this condition results in a higher recovery of total IAPP but not of insulin, suggesting that the failure to increase insulin formation is responsible for the increased ratio in cellular IAPP over insulin (Table 2). In contrast to rat beta cells, a combination of the IBMX and glucose stimuli does not further increase the IAPP and insulin content in the medium, nor the total recovery of these peptides, but reduces the cellular content in both IAPP and insulin (Table 2); consequently, the cellular ratio of IAPP over insulin is similar to that after $20 \mathrm{mmol} / \mathrm{l}$ glucose culture (Table 2). Conceivably, addition of IBMX to the high glucose medium does not further stimulate synthesis, leading to lower cellular reserves of both IAPP and insulin and to a restriction of the amount of hormone that can be released under continued stimulation.

Characterisation of IAPP-like peptides in cultured human beta cells. After culture at $6 \mathrm{mmol} / \mathrm{l}$ glucose, human beta cells show three IAPP immunoreactive bands in western blot with positions similar to those found in the rat (Fig. 3). In contrast to their proportion in rat beta cells, the mature $4 \mathrm{kDa}$ species is the least prominent and the intermediate band the predominant form (Fig. 3). This band was characterised by a selective immunoreactivity with the $\mathrm{N}$-terminal flanking peptide-specific antibody but could not be stained by the C-terminal flanking peptide-specific antibody (Fig. 1). Culture with IBMX or $20 \mathrm{mmol} / \mathrm{l}$ glucose further reduced the proportion of the $4 \mathrm{kDa}$ band, an effect that was only statistically significant for IBMX (Fig. 3). In freshly isolated human islet cells $90 \%$ of IAPP was present in the mature $4 \mathrm{kDa}$ form, which is considerably higher than in 3 days cultured preparations ( $40 \%$, Fig. 3 ).

\section{Discussion}

The secretory activity of pancreatic beta cells can be stimulated by glucose as well as by cAMP elevating agents [12]. Culture of rat and human beta cells at 
Table 2. IAPP and insulin contents in human islet cells and culture media

\begin{tabular}{|c|c|c|c|c|c|c|c|}
\hline \multirow{2}{*}{$\begin{array}{l}\text { Culture } \\
\text { Condition: }\end{array}$} & \multicolumn{3}{|l|}{ Cell } & \multicolumn{2}{|l|}{ Medium } & \multicolumn{2}{|l|}{ Total } \\
\hline & $\begin{array}{l}\text { IAPP } \\
\text { (pmol/ } \\
\text { fraction) }\end{array}$ & $\begin{array}{l}\text { insulin } \\
\text { (nmol/ } \\
\text { fraction) }\end{array}$ & $\begin{array}{l}\text { Ratio } \\
\text { IAPP/ } \\
\text { insulin (\%) }\end{array}$ & 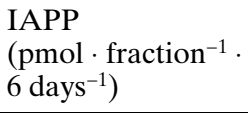 & $\begin{array}{l}\text { insulin } \\
\left(\text { nmol }^{- \text {fraction }^{-1}} \text {. }\right. \\
\left.6 \text { days }^{-1}\right)\end{array}$ & $\begin{array}{l}\text { IAPP } \\
\text { (pmol/ } \\
\text { fraction) }\end{array}$ & $\begin{array}{l}\text { insulin } \\
\text { (nmol/ } \\
\text { fraction) }\end{array}$ \\
\hline \multicolumn{8}{|c|}{ Glucose $6 \mathrm{mmol} / \mathrm{l}(n)$} \\
\hline Control (7) & $83 \pm 32$ & $5.7 \pm 1.9$ & $1.8 \pm 0.3$ & $121 \pm 20$ & $8.0 \pm 1.2$ & $203 \pm 43$ & $13.8 \pm 2.6$ \\
\hline $\operatorname{IBMX}(5)$ & $46 \pm 14$ & $3.1 \pm 0.9$ & $1.7 \pm 0.6$ & $303 \pm 110^{\mathrm{a}}$ & $20.5 \pm 2.2^{\mathrm{a}}$ & $349 \pm 117$ & $23.6 \pm 2.5^{\mathrm{a}}$ \\
\hline \multicolumn{8}{|c|}{ Glucose $20 \mathrm{mmol} / \mathrm{l}(n)$} \\
\hline Control (7) & $53 \pm 16$ & $2.3 \pm 1.0^{\mathrm{b}}$ & $3.0 \pm 0.6^{b}$ & $337 \pm 83^{b}$ & $15.7 \pm 3.4^{\mathrm{b}}$ & $390 \pm 89^{b}$ & $18.0 \pm 3.6$ \\
\hline IBMX (7) & $26 \pm 10^{c}$ & $0.8 \pm 0.2^{\mathrm{c}}$ & $3.3 \pm 0.9^{\mathrm{bc}}$ & $329 \pm 78^{c}$ & $15.3 \pm 3.0^{\mathrm{c}}$ & $355 \pm 88$ & $16.1 \pm 3.1$ \\
\hline
\end{tabular}

Human islet cells were cultured in HAM-F10 (supplemented with $2 \mathrm{mmol} / \mathrm{l} \mathrm{CaCl}_{2}$ ) for 6 days. Insulin and IAPP contents in cellular extracts and medium were measured by radio immuno assay. Data represent means of $(n)$ independent experi- ments \pm SEM, a $p<0.05$ vs control at corresponding glucose, ${ }^{\mathrm{b}} p<0.05$ vs corresponding condition at $6 \mathrm{mmol} / \mathrm{l}$ glucose, ${ }^{c} p<0.05$ vs $6 \mathrm{mmol} / \mathrm{l}$ glucose control

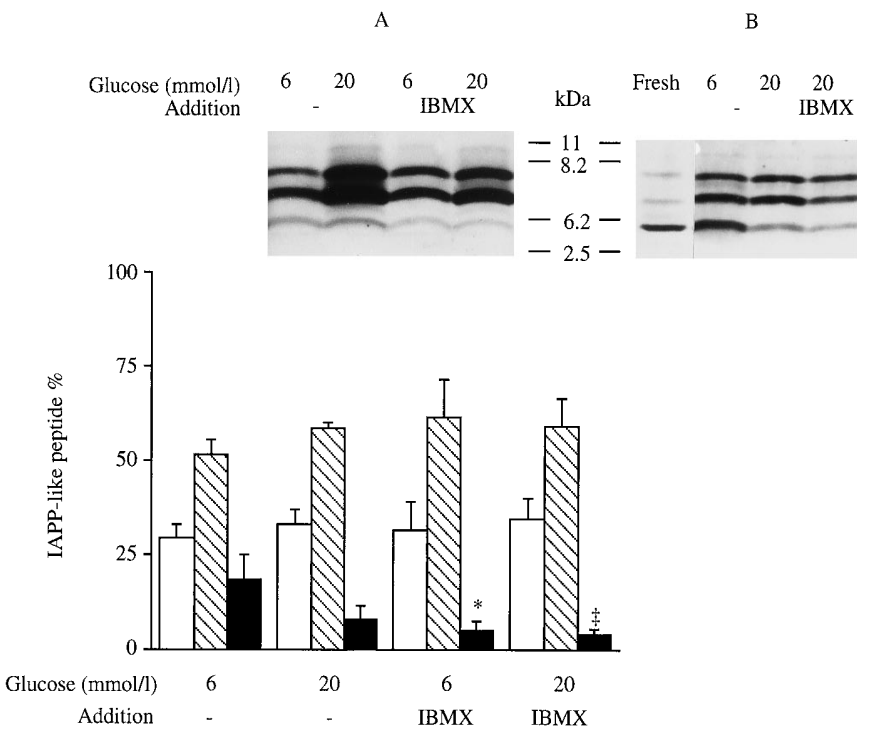

Fig.3. A Western blot analysis of IAPP-like immunoreactivity in human islet cells after culture under the indicated conditions for 6 days. The upper panel shows a representative blot. Scanning data are obtained from 4 dependent experiments and expressed as per cent of total IAPP-like immunoreactivity (lower panel). The $7.5 \mathrm{kDa}$ species is represented by open bars, the intermediate species by hatched bars and the mature $4 \mathrm{kDa}$ species by black bars. Data are presented as means $\pm \operatorname{SEM} n=4$. $* p<0.05$ vs control at corresponding glucose, $\ddagger p<0.05$ vs $6 \mathrm{mmol} / \mathrm{l}$ glucose control. B Western blot analysis in human islet cells immediately after isolation (fresh) or after culture under the indicated conditions for 3 days

$20 \mathrm{mmol} / \mathrm{l}$ glucose or in the presence of a phosphodiesterase inhibitor resulted in higher release of both insulin and IAPP. In rat preparations, these conditions of stimulated release appeared associated with an increased production of the hormones, which is expected to sustain a pronounced accumulation of extra cellular insulin and IAPP, 4- to 15-fold higher than control, without reduction in cellular insulin or IAPP content. In human preparations, the rise in hormone production was only barely significant, which might explain the decline in the cellular hormone content and the less pronounced accumulation of extra cellular hormone, 2- to 3-fold higher than in the $6 \mathrm{mmol} / \mathrm{l}$ glucose control. Our assessment of hormone production during culture was based on the total hormone amounts that were recovered from cells plus medium; this method is rather indirect and requires confirmation by direct assays of the rates of insulin and IAPP biosynthesis. It is also necessary to examine whether the observed difference is influenced by the longer culture of human beta cell preparations ( 6 as opposed to 3 days for rat preparations). These experiments were not planned in the present study, as our intention was to investigate the effect of a prolonged stimulation of beta cells on the molecular forms of cellular IAPP. With the same objective, beta cells were cultured in the presence of both IBMX and high glucose. Addition of IBMX to the $20 \mathrm{mmol} / \mathrm{l}$ glucose medium was found to also affect the cellular content in insulin and IAPP parallel to the effects of this condition on insulin and IAPP formation, respectively. Prolonged exposure of beta cells to high glucose concentrations thus resulted in varying reductions in the cellular insulin or IAPP content. The variation appeared to be attributable to at least two factors. One is the degree to which the stimulatory condition caused an imbalance between the rates of hormone synthesis and release: both in rat and human beta cells, this imbalance occurred more rapidly for insulin than for IAPP resulting in an increased ratio of the cellular IAPP over insulin contents. It should be noted that this effect could only be underestimated by incomplete cross reactivity of pro-IAPP in the radioimmunoassay. Such increase in ratio can be explained by differences in transcriptional control of insulin and IAPP formation $[18,19]$. The other factor is species-related, human beta cells exhibiting a more pronounced reduction in cellular hormone content than rat beta cells. The relative failure of human beta cells to sufficiently increase their rates of hormone synthesis when cultured in $20 \mathrm{mmol} / \mathrm{l}$ instead of $6 \mathrm{mmol} / \mathrm{l}$ glucose is consistent 
with previous data indicating that the rate of insulin synthesis in $6 \mathrm{mmol} / \mathrm{l}$ cultured human beta cells is already close to maximum whereas this is not the case in cultured rat beta cells $[14,20]$.

We examined whether prolonged stimulation of beta cells influenced the form of cellular IAPP. Western blots of cellular extracts indicated the presence of IAPP-immunoreactive bands with a higher MW than $4 \mathrm{kDa}$. They were identified as IAPP precursor forms since 1) the $7.5 \mathrm{kDa}$ band corresponded to the only band that was labelled following a pulse with ${ }^{35} \mathrm{~S}$-cysteine short enough to keep the majority of precursor unprocessed [21];2) this $7.5 \mathrm{kDa}$ band, but not the intermediate band, reacted with C-terminal flanking peptide-specific antibody; 3 ) both the 7.5 and the intermediate band exhibited an immunoreactivity with an N-terminal flanking peptide-specific antibody; 4) no mobility shift in $20 \%$ SDS PAGE and western blot was observed among the major bands after enzymatic deglycosylation, although the disappearance of the faint bands above the full precursor and the intermediate suggests that a small proportion of proIAPP could be glycosylated. The combined immunoreactivity for both flanking peptides is consistent with the 7.5 $\mathrm{kDa}$ band being the full precursor form of pro-IAPP. It also indicates that the $7.5 \mathrm{kDa}$ band is not a dimeric form of mature IAPP; such dimers would indeed lack any immunoreactivity with the flanking peptide antibodies and would not be stable under the reducing SDS-PAGE conditions. Furthermore, dimeric forms are unlikely in rat beta cells as this species lacks amyloidogenic IAPP. The intermediate band runs slightly above the $6.2 \mathrm{kDa}$ marker but corresponds to a 5.7 $\mathrm{kDa}$ position upon interpolation from the band positions of mature IAPP and its full precursor. This size is close to that of the IAPP-intermediate as derived from its sequence. An absolute difference of approximately $1 \mathrm{kDa}$ falls within the resolution of the present method, considering the influences of intrinsic net charge and structure on the migration velocity of small peptides in SDS-PAGE [22]. The three IAPPimmunoreactive bands could be analysed semi-quantitatively, since the selected conditions were found to yield reproducible results with no peptide losses during electrotransfer and with a dose linearity of more than one magnitude.

In the three tested conditions of prolonged betacell stimulation, we detected an increased proportion of IAPP precursors in the cellular extracts. This relative abundance of IAPP precursors might result from a combination of increased rates of synthesis (present data) and a saturation of the IAPP processing activity $[21,23]$. This would be expected to lead to the release of a higher proportion of precursor- and intermediate forms, similar to the relative hypersecretion of proinsulin from tissue with a higher proportion of this precursor [24]. A high proportion of IAPP precursors has been observed in culture media of the stimulating conditions but we have not yet completed a systematic study of the released forms, mainly because of detection problems in the basal control media. The additional faint bands present in these samples should also be further analysed as to their possible nature as glycosylated forms of proIAPP. Comparison of rat and human beta cells cultured in the $6 \mathrm{mmol} / \mathrm{l}$ glucose control condition indicated the presence of a higher proportion of IAPP precursor and intermediate forms in human beta cells. This difference was also observed when both preparations had been cultured for 3 days. It is not present in freshly isolated cells which exhibit a predominance of the mature form. The proportionally higher abundance of IAPP precursors in cultured human beta cells - as compared to cultured rat $\beta$ cells - can therefore be attributed to their higher degree of activation at this glucose concentration $[14,20]$. We can, however, not exclude an influence of other variables, such as the degree of tissue dispersion and the presence of other cell types (as, for example, glucagon-containing alpha cells).

It is unclear whether intra and/or extra cellular accumulation of IAPP precursors and intermediates promotes the formation of amyloid fibrils. The flanking sequences of these molecules carry a high proportion of amino acids that frequently occur in the betapleated sheets that constitute amyloid; furthermore, human islet amyloid exhibits immunoreactivity for the N-terminal flanking peptide [10]. A rise in local IAPP concentrations certainly facilitates fibril formation $[25,26]$, in particular of the N-terminally extended intermediate which is more stable than its C-terminally extended counterpart that carries an additional lys-arg processing site in its flanking sequence [1].

The presently described conditions can be used to investigate whether amyloid fibrils develop following prolonged exposure of beta cells to elevated glucose levels, and, if so, whether they originate in intracellular sites [27] or in the extra cellular space. The outcome of these experiments will determine to which extent the present observations are relevant for the development of amyloid in patients with non-insulin dependent diabetes.

Acknowledgements. The authors thank the team of the central unit of Beta-Cell Transplant for the preparation of human islets, and their collaborators at the Diabetes Research Center for their help in preparing the rat islet beta cells. G. Schoonjans is acknowledged for doing the insulin immune assays and R. Deproft and A. De Loof for their technical assistance in the human islet experiments. We are grateful to A. Clark for her advice during preparation of our manuscript and to her and C. Baker and J. Hutton for antibodies to proIAPP peptides. This work was supported by grants from the Flemish Community (GOA 92/97-1807), the Belgian 'Fonds voor Geneeskundig Wetenschappelijk Onderzoek' (F.G.W.O. 3.0132.91), from BIOMED (BMH I - CT 92-0805, BMH4-CT95-1561) and the Juvenile Diabetes Foundation (NIH/JDF Diabetes Interdisciplinary Research Program Grant 1995-2000). 


\section{References}

1. Sanke T, Bell GI, Sample C, Rubenstein AH, Steiner DF (1988) An islet amyloid peptide is derived from an 89-amino acid precursor by proteolytic processing. J Biol Chem 263: $17243-17246$

2. Westermark P, Grimelius L (1973) The pancreatic islet cell in insular amyloidosis in human diabetic and non-diabetic islets. Acta Path Microbiol Scand A 81: 291-300

3. Clark A, Cooper GJS, Lewis CE, Morris JF, Willis AC, Reid KBM (1987) Islet amyloid formed from diabetes associated peptide may be pathogenic in Type- 2 diabetes. Lancet ii: $231-234$

4. Betsholtz C, Christmansson L, Engström U et al. (1989) Sequence divergence in a specific region of islet amyloid polypeptide (IAPP) explains differences in islet amyloid formation between species. FEBS Lett 251: 261-264

5. Betsholtz C, Christmansson L, Engström U et al. (1990) Structure of cat islet amyloid polypeptide and identification of amino acid residues of potential significance for islet amyloid formation. Diabetes 39: 118-122

6. Johnson KH, O'Brien TD, Betsholtz C, Westermark P (1992) Biology of disease islet amyloid polypeptide: mechanisms of amyloidogenesis in the pancreatic islets and potential roles in diabetes mellitus. Laboratory Investigation 66: 522-535

7. O'Brien TD, Butler AE, Roche PC, Johnson KH, Butler PC (1994) Islet amyloid polypeptide in human insulinomas, evidence for intracellular amyloidogenesis. Diabetes 43: 329-336

8. Verchere CB, D'Alessio DAD, Wang S, Andrikopoulos S, Kahn SE (1997) Transgenic overproduction of islet amyloid polypeptide (amylin) is not sufficient for islet amyloid formation. Horm Metab Res 29: 311-316

9. Percy AJ, Trainor DA, Rittenhouse J, Phelps J, Koda JE (1996) Development of sensitive immunoassays to detect amylin and amylin-like peptides in unextracted plasma. Clin Chem 42: 576-585

10. Westermark P, Engström U, Westermark GT, Johnson KH, Permerth J, Betsholtz C (1989) Islet amyloid polypeptide (IAPP) and pro-IAPP immunoreactivity in human islets of Langerhans. Diabetes Res Clin Pract 7: 219-226

11. Pipeleers DG, In't Veld PA, Van De Winkel M, Mase E, Schuit FC, Gepts W (1985) A new in vitro model for the study of pancreatic A and B cells. Endocrinology 117: 806-816

12. Pipeleers DG, Schuit FC, In't Veld PA et al. (1985) Interplay of nutrients and hormones in the regulation of insulin release. Endocrinology 117: 824-833

13. Pipeleers DG (1994) Treatment of diabetes by islets cell transplantation. In: Baya C (ed) Biomedical and Health Reserarch Vol. 3. Adv Med Biol IOS Press, Amsterdam pp 185-197

14. Ling ZD, Pipeleers DG (1996) Prolonged exposure of human beta cells to elevated glucose levels results in sus- tained cellular activation leading to a loss of glucose regulation. J Clin Invest 98: 2805-2812

15. Schägger H, Jagow GV (1987) Tricine-sodium dodecyl sulfate-polyacrylamide gel electrophoresis for the separation of proteins in the range from 1 to $100 \mathrm{kDa}$. Analytical Biochemistry 166: 368-379

16. Gorus FK, Sodoyez JC, Pipeleers DG et al. (1992) Detection of autoantibodies against islet amyloid polypeptide in human serum. Lack of association with Type-I (insulin-dependent) diabetes mellitus, or with conditions favouring amyloid deposition in islets. Diabetologia 35: 1080-1086

17. Hou X, Ling Z, Zambre Y et al. (1997) Proinsulin and its conversion intermediates in human pancreas and isolated islet tissue: kinetics and steady state analysis. Pancreas 15 (2): $113-121$

18. Gasa R, Gomis R, Casamitjana R, Rivera F, Novials A (1997) Glucose regulation of islet amyloid polypeptide gene expression in rat pancreatic islets. Am J Physiol 272: E543-E549

19. Gasa R, Gomis R, Casamitjana R, Rivera F, Novials A (1997) Signals related to glucose metabolism regulate islet amyloid polypeptde (IAPP) gene expression in human pancreatic islets. Regulatory Peptides 68: 99-104

20. Schuit FC, In't Veld PA, Pipeleers DG (1988) Glucose stimulates proinsulin biosynthesis by a dose-dependent recruitment of pancreatic beta cells. Proc Natl Acad Sci 85: 3865-3869

21. Nagamatsu S, Nishi M, Steiner DF (1991) Biosynthesis of islet amyloid polypeptide. Elevated expression in mouse betaTC3 cells. J Biol Chem 266(21):13737-13741

22. Kratzin HD, Wiltfang J, Karas M, Neuboff V, Hilschmann $\mathrm{N}$ (1989) Gasphase sequencing after electroblotting on polyvinylidene difluoride membranes assigns correct molecular weights to myoglobin molecular weight markers. Analytical Biochem 183: 1-8

23. Badman MK, Shennan KIJ, Jermany JL, Docherty K, Clark A (1996) Processing of pro-islet amyloid polypeptide (proIAPP) by the prohormone convertase PC2. FEBS Lett 378: 227-231

24. Leahy JL, Halban PA, Weir GC (1991) Relative hypersecretion of proinsulin in a rat model of NIDDM. Diabetes 40: 985-989

25. de Koning EJP, Morris ER, Hofhuis FMA et al. (1994) Intra and extracellular amyloid fibris are formed in cultured pancreatic islets of transgenic mice expressing human islet amyloid polypeptide. Proc Natl Acad Sci USA 91: 8467-8471

26. Kanatsuka A, Makino H, Ohsawa H et al. (1989) Secretion of islet amyloid polypeptide in response to glucose. FEBS Lett 259: 199-201

27. Westermark P, Eizirik DL, Pipeleers DG, Hellerström C, Andersson A (1995) Rapid deposition of amyloid in human islets transplanted into nude mice. Diabetologia 38: 543549 